\title{
Defining a standard metric for electricity savings
}

\author{
Jonathan Koomey ${ }^{1,2}$, Hashem Akbari, Carl Blumstein, \\ Marilyn Brown, Richard Brown, Chris Calwell, \\ Sheryl Carter, Ralph Cavanagh, Audrey Chang, \\ David Claridge, Paul Craig, Rick Diamond, Joseph H Eto, \\ William Fulkerson, Ashok Gadgil, Howard Geller, \\ José Goldemberg, Chuck Goldman, David B Goldstein, \\ Steve Greenberg, David Hafemeister, Jeff Harris, \\ Hal Harvey, Eric Heitz, Eric Hirst, Holmes Hummel, \\ Dan Kammen, Henry Kelly, Skip Laitner, Mark Levine, \\ Amory Lovins, Gil Masters, James E McMahon, Alan Meier, \\ Michael Messenger, John Millhone, Evan Mills, Steve Nadel, \\ Bruce Nordman, Lynn Price, Joe Romm, Marc Ross, \\ Michael Rufo, Jayant Sathaye, Lee Schipper, \\ Stephen H Schneider, James L Sweeney, Malcolm Verdict, \\ Diana Vorsatz, Devra Wang, Carl Weinberg, Richard Wilk, \\ John Wilson and Ernst Worrell

\footnotetext{
${ }^{1}$ Lawrence Berkeley National Laboratory and Stanford University, PO Box 20313, Oakland, CA 94620-0313, USA
}

E-mail: JGKoomey@stanford.edu

Received 30 March 2009

Accepted for publication 8 June 2009

Published 9 March 2010

Online at stacks.iop.org/ERL/5/014017

\begin{abstract}
The growing investment by governments and electric utilities in energy efficiency programs highlights the need for simple tools to help assess and explain the size of the potential resource. One technique that is commonly used in this effort is to characterize electricity savings in terms of avoided power plants, because it is easier for people to visualize a power plant than it is to understand an abstraction such as billions of kilowatt-hours. Unfortunately, there is no standardization around the characteristics of such power plants.

In this letter we define parameters for a standard avoided power plant that have physical meaning and intuitive plausibility, for use in back-of-the-envelope calculations. For the prototypical plant this article settles on a $500 \mathrm{MW}$ existing coal plant operating at a $70 \%$ capacity factor with 7\% T\&D losses. Displacing such a plant for one year would save 3 billion $\mathrm{kWh} /$ year at the meter and reduce emissions by 3 million metric tons of $\mathrm{CO}_{2}$ per year.

The proposed name for this metric is the Rosenfeld, in keeping with the tradition among scientists of naming units in honor of the person most responsible for the discovery and widespread adoption of the underlying scientific principle in question-Dr Arthur H Rosenfeld.
\end{abstract}

Keywords: electricity savings, energy efficiency, energy policy, climate change solutions, coal-fired power plants, back-of-the-envelope calculations, Arthur H Rosenfeld

2 www.koomey.com. 


\section{Introduction}

In the three decades since the energy crises of the 1970s we have learned a great deal about the potential for energy efficiency and the means to deliver it cost effectively and reliably (Rosenfeld 1999). Back then, many analysts still held to the now discredited 'ironclad link' between energy use and economic activity, which implied that any reduction in energy use would make our society less wealthy (Craig et al 2002, Koomey 1984, Levine and Craig 1985, Lovins 1979). Now we know (from cross-country comparisons and technical analysis) that there are many ways to produce and consume goods and services, some energy efficient and others not (Carnahan et al 1975, Darmstadter et al 1977, International Energy Agency (IEA) 1997, Schipper and Lichtenberg 1976, Schipper et al 1992). And we know that the available efficiency resources are enormous, inexpensive, and largely untapped (particularly if whole-system clean-slate redesign is employed), making them an important option for reducing climate risks and improving energy security (APS 2008, Brohard et al 1998, Brown et al 2001, Lovins 2005, Lovins et al 2004). Finally, we know that tapping these resources requires more than getting energy prices right - we will also need to further develop and implement cost-benefit-tested non-price policies like minimum efficiency standards, Energy Star labeling programs, utility rebates, 'Golden Carrot' incentives, research and development, tax credits, and other programs whose goal is to align private financial incentives with the economic and environmental interests of society as a whole (APS 2008, Brown et al 2001, Koomey 1990, Koomey et al 1996, 2001, Krause and Eto 1988, Krause et al 1993, Krause et al 1995, Lovins 1992, Lovins et al 2004).

The increased focus on energy efficiency for shaping our energy future highlights the need for simple tools to help understand and explain the size of the potential resource. One technique that is commonly used in that effort is to characterize electricity savings in terms of avoided power plants, because it is easier for people to visualize a power plant than it is to understand an abstract concept like billions of kilowatt-hours. Unfortunately, there is no standardization around the size and operational characteristics of such plants.

In this letter we propose standard characteristics for an avoided power plant that have physical meaning and intuitive plausibility, for use in back-of-the-envelope calculations and characterizing energy savings results. We also propose naming the annual energy savings of such a plant as a new unit in Art Rosenfeld's honor (the Rosenfeld) because Dr Rosenfeld continues to be the most prominent advocate of characterizing efficiency savings in terms of avoided power plants.

\section{Arthur H Rosenfeld's contributions}

Dr Rosenfeld (figure 1) made a transition from particle physics to studying energy efficiency at the time of the first oil embargo (Rosenfeld 1999). Over the past 35 years he has been at the forefront of efforts to improve the efficiency of energy use around the world and has devoted special care to making the results of complex energy analysis understandable to a

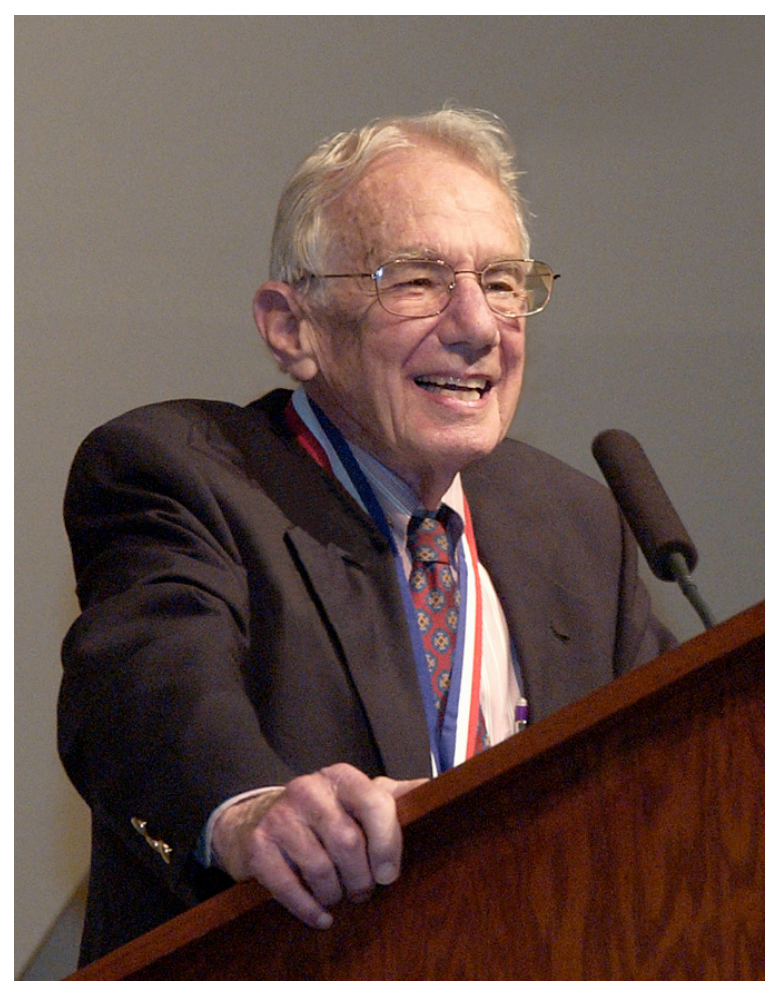

Figure 1. Arthur H Rosenfeld.

lay audience. For years, Dr Rosenfeld has characterized oil savings in terms of 'Arctic Refuges saved' and electricity savings in terms of 'avoided power plants' to emphasize that supply and demand side policy options are fungible and that replacing power plants with more efficient energy technologies would be beneficial for consumers' electricity bills and for the environment.

Dr Rosenfeld has in the past most commonly used a 1000 MW power plant operating at a 60 or $65 \%$ capacity factor as the standard power plant avoided by energy efficiency. These assumptions mirrored the capacity and operational characteristics of typical US nuclear power plants circa 1990, but since that time the capacity factors of such plants have increased to about $90 \%$. No new nuclear plants have been completed in the US since 1996, so the appropriateness of this choice of assumptions has decreased over time. More recently, Dr Rosenfeld has used a 500 MW plant operating $5000 \mathrm{~h}$ per year as his standard avoided plant (Rosenfeld and Kumar 2001).

\section{Criteria}

Choosing characteristics of a typical avoided power plant is inevitably somewhat arbitrary-there is no single correct answer. In our view, those choices should meet the following criteria.

(1) Simplicity of presentation and ease of recall: round numbers of one significant figure should be preferred to more accurate numbers with several decimal places of precision because they are easier to remember and use. 
Moreover, 'average' power plant sizes and capacity factors change each year, so a value with several decimal places of precision would have no longevity in any case.

(2) Intuitive plausibility: the parameters chosen should reflect people's general understanding of power plants and their operation in the utility system.

(3) Physical meaning: the chosen characteristics should reflect real-world attributes of the physical systems in which power plants are embedded and should be expressed as savings at the meter (to account for transmission and distribution losses).

(4) Policy relevance: the main result for avoided power plants would be electricity savings (which is an important metric for energy policy). Carbon savings associated with those energy savings (reflecting climate change, the most important environmental challenge facing humanity) should also be estimated, but electricity savings are the key focus. Costs and non- $\mathrm{CO}_{2}$ emissions for avoided power plants vary greatly by technology, by country, and over time, so including them would make this task needlessly complicated.

The next step is to assess the key parameters for characterizing power plants to see which choices might meet those criteria. To make that assessment easier, we add two additional constraints.

(1) We focus on power plants avoidable in the long run. Utility emissions savings can be the result of either short run operational changes or long run retirement and construction decisions. Emissions savings from operational changes are much more difficult to characterize in a general way than are long-term changes (analyzing the former is very situation dependent and typically requires complicated production-cost/dispatch simulation modeling).

(2) We assume that the standard avoided power plant should be coal-fired. Between 2000 and 2007, 151 new coal-fired power plants were proposed in the United States; 10 have been completed, 25 more are under construction, and 59 have been canceled or indefinitely deferred (Calwell and Moorefield 2008). In 2007, existing coal plants totaled more than $300 \mathrm{GW}$ (out of almost $1000 \mathrm{GW}$ total installed capacity in the US).

Coal plants generate about half of all US electricity and were responsible for about one third of total US carbon emissions in 2007. They are also ubiquitous in other countries responsible for substantial percentages of world carbon emissions (e.g., China and India). Truly facing the climate challenge will require the retirement or displacement of hundreds or thousands of such plants (Black 2009, Caldeira et al 2003, Krause et al 1992, Meinshausen et al 2009). Finally, the capacity factors of coal plants are relatively insensitive to fuel price changes (compared to natural gas plants) so their operational characteristics are more predictable than for some other plants.

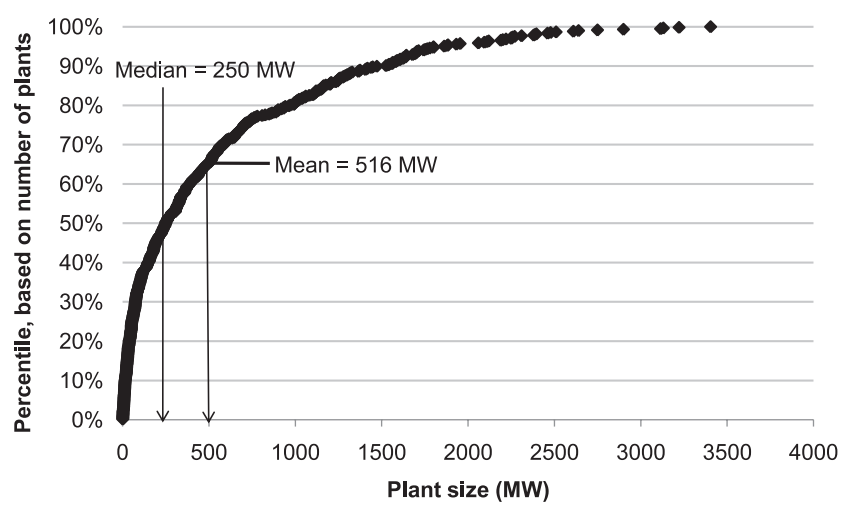

Figure 2. Cumulative distribution of capacity for existing US coal-fired power plants in 2007. Source: US Energy Information Administration, form EIA-860 Annual Generator Report Database (www.eia.doe.gov/cneaf/electricity/page/eia860.html).

\section{Characteristics of coal-fired power plants}

This section describes our review of the literature for each key characteristic of coal-fired power plants in advance of choosing parameters for a typical plant.

\subsection{Capacity}

Power plants vary greatly in their capacity (measured in megawatts, MW, or million watts), which can be expressed as a nameplate (nominal) rating or as net capacity after subtracting out power needed to run the plant.

The Energy Information Administration or EIA (US DOE 2009a) gives characteristics of new conventional power plants for the US. Pulverized coal plants with scrubbers fall at $600 \mathrm{MW}$.

As shown in figure $2^{3}$ the median nameplate capacity for existing non-cogenerating US coal plants in 2007 was $250 \mathrm{MW}$, with a mean of about $500 \mathrm{MW}$ and a range of less than a megawatt to about $3500 \mathrm{MW}$ (www.eia.doe.gov/cneaf/ electricity/page/eia860.html). Most of the smaller plants (less than $200 \mathrm{MW}$ ) tend to be older (1960s or earlier), while the larger plants tend to be newer (1970s or later).

EIA's Electric Power Annual 2007 (US DOE 2009b) shows that total capacity for US coal-fired power generation is remarkably stable over the period 1996-2007, starting and ending at just over $300 \mathrm{GW}$ (table 1). There have been a few retirements and new plants constructed, but the US has seen no significant change in total coal capacity over this period.

\subsection{Capacity factors}

The capacity factor is defined as

$$
\text { Capacity factor }=\frac{\text { Actual generation } / \text { year }(\mathrm{BkWh})}{\text { Maximum generation } / \text { year }(\mathrm{BkWh})} \text {. }
$$

3 See Koomey and Hultman (2007) for similar cumulative distribution graphs describing historical data on nuclear power plants in the US. 
Table 1. Characteristics of existing US coal-fired power plants.

\begin{tabular}{|c|c|c|c|c|c|c|}
\hline & $\begin{array}{l}\text { Coal-fired } \\
\text { capacity (GW) }\end{array}$ & $\begin{array}{l}\text { Net generation } \\
\text { (TWh) }\end{array}$ & $\begin{array}{l}\text { Capacity } \\
\text { factor }(\%)\end{array}$ & $\begin{array}{l}\text { Coal consumed } \\
\text { (million short tons) }\end{array}$ & $\begin{array}{l}\text { Heat content of utility } \\
\text { coal (MBtu/short ton) }\end{array}$ & $\begin{array}{l}\text { Average HHV } \\
\text { efficiency }(\%)\end{array}$ \\
\hline 1996 & 313 & 1795 & 65.2 & 907 & 20.55 & 32.9 \\
\hline 1997 & 314 & 1845 & 67.2 & 932 & 20.52 & 32.9 \\
\hline 1998 & 316 & 1874 & 67.7 & 946 & 20.52 & 32.9 \\
\hline 1999 & 315 & 1881 & 68.1 & 950 & 20.49 & 33.0 \\
\hline 2000 & 315 & 1966 & 71.0 & 995 & 20.51 & 32.9 \\
\hline 2001 & 314 & 1904 & 69.2 & 973 & 20.34 & 32.8 \\
\hline 2002 & 315 & 1933 & 70.0 & 988 & 20.24 & 33.0 \\
\hline 2003 & 313 & 1974 & 72.0 & 1014 & 20.08 & 33.1 \\
\hline 2004 & 313 & 1978 & 71.9 & 1021 & 19.98 & 33.1 \\
\hline 2005 & 313 & 2013 & 73.3 & 1041 & 19.99 & 33.0 \\
\hline 2006 & 313 & 1991 & 72.6 & 1031 & 19.93 & 33.1 \\
\hline 2007 & 313 & 2016 & 73.6 & 1047 & 19.91 & 33.0 \\
\hline Average & & & 70.2 & & & 33.0 \\
\hline
\end{tabular}

${ }^{a}$ Coal consumed, capacity, and net generation include all coal-fired power plants in the US, including utility and non-utility central station plants as well as industrial cogeneration plants.

${ }^{\mathrm{b}}$ Coal-fired capacity, net generation and coal consumed taken from US DOE (2009b). Heat content of coal taken from table A-5 in US DOE (2008). MBtu = million Btus.

${ }^{\mathrm{c}}$ Capacity factor calculated from capacity and net generation assuming $8760 \mathrm{~h}$ for non-leap years and $8784 \mathrm{~h}$ for leap years.

${ }^{\mathrm{d}}$ Power plant efficiency (higher heating value) calculated by converting net generation to Btus assuming $3412 \mathrm{Btus}^{\mathrm{kWh}}{ }^{-1}$ and then dividing by the product of coal consumed and heat content of utility coal.

Table 2. US average transmission and distribution (T\&D losses) over time.

\begin{tabular}{lccccc}
\hline & $\begin{array}{l}\text { Total electric industry } \\
\text { sales (TWh) }\end{array}$ & $\begin{array}{l}\text { Direct use } \\
(\mathrm{TWh})\end{array}$ & $\begin{array}{l}\text { Total exports } \\
(\mathrm{TWh})\end{array}$ & $\begin{array}{l}\text { Losses and } \\
\text { unaccounted for (TWh) }\end{array}$ & $\begin{array}{c}\text { T\&D } \\
\text { losses }(\%)\end{array}$ \\
\hline 1996 & 3101 & 153 & 3 & 231 & 7.1 \\
1997 & 3146 & 156 & 9 & 224 & 6.8 \\
1998 & 3264 & 161 & 14 & 221 & 6.4 \\
1999 & 3312 & 172 & 14 & 240 & 6.9 \\
2000 & 3421 & 171 & 15 & 244 & 6.8 \\
2001 & 3394 & 163 & 16 & 202 & 5.7 \\
2002 & 3465 & 166 & 16 & 248 & 6.8 \\
2003 & 3494 & 168 & 24 & 228 & 6.2 \\
2004 & 3547 & 168 & 23 & 266 & 7.1 \\
2005 & 3661 & 150 & 20 & 269 & 6.0 \\
2006 & 3670 & 147 & 24 & 266 & 6.7 \\
2007 & 3765 & 159 & 20 & 264 & 6.7 \\
Average & & & & & \\
\hline
\end{tabular}

${ }^{a}$ Data on electric industry sales, direct use, exports, and losses are taken from US DOE (2009b).

b $T \& D$ losses calculated as a percentage of sales plus direct use plus exports.

Dividing numerator and denominator by the number of hours per year $(8766 \mathrm{~h}$ when averaged across leap and nonleap years) we get

$$
\text { Capacity factor }=\frac{\text { Average output capacity (MW) }}{\text { Rated (maximum) capacity (MW) }}
$$

Coal plants can have a wide range of capacity factors: they are usually operated for baseload electricity but are flexible enough to serve all but the lowest of intermediate loads as well. Their capacity factors are relatively insensitive to coal prices though they can be influenced when the price for the main competing fuel in the power sector (natural gas) fluctuates greatly.

New coal plants typically have high capacity factors (up to $90 \%$ ). Capacity factors for existing plants in the US increased significantly over the 1996-2007 period, averaging about $70 \%$ (as shown in table 1). The stock of existing plants includes many older plants that are smaller, less efficient, and more polluting than new plants. They have long since been depreciated, so utilities have an incentive to keep them running as long as the marginal costs are not too high (and as long as environmental regulations do not impose additional costs or constraints that make them uneconomic).

\subsection{Transmission and distribution losses}

Table 2 shows data from EIA's Electric Power Annual 2007 (US DOE 2009b) on the supply and disposition of electricity in the US from 1995 to 2007 . Losses are expressed as a percentage of the sum of electricity sales, direct use by power plants, and exports. These losses range from $5.7 \%$ to $7.1 \%$ with a simple average of $6.7 \%$ over that period. 
Table 3. Direct carbon emissions factors for fuels used by utilities to generate electricity.

\begin{tabular}{lcrcc}
\hline & & & & \multicolumn{2}{c}{ Index } \\
& M tons C/quad & $\mathrm{kg} \mathrm{C} / \mathrm{GJ}$ & $\mathrm{gC} / \mathrm{kWh.f}$ & $\mathrm{NG}=1.0$ \\
\hline Natural gas & 14.47 & 13.7 & 49.4 & 1.00 \\
Distillate oil & 19.95 & 18.9 & 68.1 & 1.38 \\
Residual oil & 21.29 & 20.2 & 72.6 & 1.47 \\
Coal & 25.83 & 24.5 & 88.1 & 1.78 \\
\hline
\end{tabular}

${ }^{\text {a }}$ Carbon emissions factors (Mt-C/quadrillion Btus) taken from EIA data for 2006 (downloaded from www.eia.doe.gov/environment. $\mathrm{html}$ ). It is unclear if these data have already built in a combustion fraction but we assume so. Combustion fractions are typically very close to 1.0 for fossil fuels in utility plants in any case.

${ }^{\mathrm{b}}$ All energy values based on higher heating value (HHV) of the fuels.

${ }^{\mathrm{c}} \mathrm{kWh} . \mathrm{f}=$ energy content of fuel converted to $\mathrm{kWh}$ using $3412 \mathrm{Btu} \mathrm{kWh}^{-1}$.

\subsection{Carbon emissions factors for fossil fuels}

The EIA (www.eia.doe.gov/environment.html) gives historical data on the carbon content of fuels for US electric utilities. The data for the latest year available (2006), expressed in higher heating value (HHV) terms, are shown in table 3. Coal emits almost $80 \%$ more carbon than natural gas per unit of heat released.

\subsection{Power plant efficiencies}

Large coal steam plants have HHV efficiencies of 30-40\%, depending on their age, level of pollution control, and technology type. For typical new $600 \mathrm{MW}$ coal plants in 2008 , EIA gives an estimate of $37 \%$ HHV efficiency (US DOE 2009a). The average efficiency of existing coal steam plants in the US for the period 1996-2007, derived using the heat content of utility coal from US DOE (2008) and the other parameters in table 1 , is $33 \%$, which does not vary much over this period.

\section{Defining the Rosenfeld}

We experimented with different combinations of plant capacities and capacity factors to meet the criteria listed above, focusing mainly on the characteristics of existing US coal plants. We choose this approach because of the rich data characterizing these plants and because most existing coal plants will need to be retired if we're to substantially reduce carbon emissions by the middle of this century, as climate stabilization requires.

As summarized in table 4 and figure 3, we've defined the Rosenfeld unit assuming the average coal plant capacity of $500 \mathrm{MW}$, a capacity factor of $70 \%$ (the average capacity factor of existing US coal plants from 1996 to 2007), and systemwide T\&D losses of $7 \%$ (rounded up from $6.7 \%$ for ease of recall). This combination of parameters would yield annual electricity delivered at the meter of about $3 \mathrm{BkWh} /$ year. Using the carbon burden for US utility coal and the efficiency of average existing coal steam plants, the emissions saved are almost exactly 3 million metric tons of $\mathrm{CO}_{2}\left(\mathrm{Mt} \mathrm{CO}_{2}\right)$ per year.

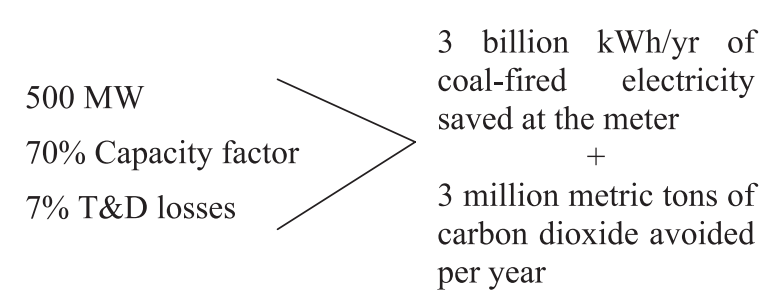

1 Exajoule (primary energy) $\sim 30$ Rosenfelds
1 Pacala/Socolow Wedge $\sim 30,000$ Rosenfelds =
600 Rosenfelds each year for 50 years

Figure 3. Summary of the Rosenfeld unit.

If measured in terms of site energy, there are 100 Rosenfelds per exajoule, and in primary energy terms there are about 30 Rosenfelds per exajoule. Another nice equivalence factor that emerges from these numbers is that each kilowatthour of coal-fired electricity delivered to the meter emits about $1 \mathrm{~kg}$ of $\mathrm{CO}_{2}$.

\section{Using the Rosenfeld}

This simplification aids in the creation of quick calculations and cogent interpretation of analysis results from studies of energy efficiency. To use the Rosenfeld, analysts have to remember the numbers associated with the power plant characteristics $(500 \mathrm{MW}, 70 \%$ capacity factor, 7\% T\&D losses, $33 \% \mathrm{HHV}$ efficiency), and the number 3 (which evokes 3 billion $\mathrm{kWh}$ saved at the meter, 3 million metric tons of carbon dioxide avoided per year, and 30 Rosenfelds per exajoule of primary energy).

Consider the recent authoritative study on energy efficiency by the American Physical Society (APS 2008). Figure 25 in that study shows potential US residential sector efficiency savings of almost 600 billion kWh/year in 2030 . What does that number mean in terms of power plants avoided?

Six hundred billion $\mathrm{kWh} /$ year is the equivalent of about 200 Rosenfelds (600/3), or 200 typical coal-fired power plants, which together emit 600 million metric tons of $\mathrm{CO}_{2}$ per year. This simple calculation adds real physical meaning to the electricity savings (but it is no substitute for more sophisticated approaches). Other important studies that would have benefitted from using this approximation include Brown et al (2008), EPRI (2009), Koomey et al (1991), Meier et al (1983), Rosenfeld and Hafemeister (1988), Rosenfeld et al (1993), and any other efficiency potentials studies that do not include a full integrated analysis of supply and demand side options.

Another widely used approximation for understanding carbon reductions is that of the 'stabilization wedge', popularized by Pacala and Socolow (2004). Each wedge represents cumulative carbon reductions over a 50-year period of 25 billion metric tons of carbon, or 91.7 billion metric tons of $\mathrm{CO}_{2}$. Each Rosenfeld saves 3 million tons of $\mathrm{CO}_{2}$ 
Table 4. Estimating electricity delivered and carbon emitted from a typical coal plant in the US.

\begin{tabular}{llcc}
\hline & Units & Value & Notes \\
\hline Electricity generated & & & \\
Capacity & MW & 500 & $\mathrm{a}$ \\
Capacity factor & $\%$ & $70 \%$ & $\mathrm{~b}$ \\
Hours per year & Hours & 8766 & $\mathrm{c}$ \\
Assumed T\&D losses & $\%$ & $7 \%$ & $\mathrm{~d}$ \\
Total electricity generated at the busbar & Billion kWh/year & 3.07 & $\mathrm{e}$ \\
Total electricity delivered to the meter & Billion kWh/year & 2.87 & $\mathrm{f}$ \\
Site energy (HHV) & Quadrillion Btus/year & 0.010 & $\mathrm{~g}$ \\
& Exajoules/year & 0.010 & $\mathrm{~h}$ \\
Primary energy (HHV) & Quadrillion Btus/year & 0.032 & $\mathrm{i}$ \\
& Exajoules/year & 0.034 & $\mathrm{~h}$ \\
Carbon emitted & & & $\mathrm{j}$ \\
Coal carbon burden (based on HHV) & gC/kWh.fuel & 88.1 & $\mathrm{k}$ \\
Efficiency (based on HHV) & $\%$ & $33 \%$ & $\mathrm{l}$ \\
Carbon burden at the busbar & gC/kWh.elect generated & 267 & 286 \\
Carbon burden at the meter & gC/kWh.elect delivered & $\mathrm{m}$ \\
Carbon emissions & Million metric tons C/yr & 0.82 & $\mathrm{n}$ \\
& Million metric tons CO $/ \mathrm{yr}$ & 3.01 & $\mathrm{o}$ \\
\hline
\end{tabular}

${ }^{a}$ Capacity is based on average existing US coal plants from EIA-860 survey results (www.eia.doe.gov/cneaf/electricity/page/eia860.html).

${ }^{\mathrm{b}}$ Capacity factor is the average for existing US coal plants from 1996 to 2007 from table 1.

${ }^{\mathrm{c}}$ Hours per year is an average over leap years and non-leap years.

${ }^{\mathrm{d}} \mathrm{T} \& \mathrm{D}$ (transmission and distribution) losses are typical for the US utility system (from table 2), rounded up to $7 \%$ for ease of recall.

${ }^{\mathrm{e}}$ Total electricity generated at the busbar is the product of capacity, capacity factor, and hours per year, expressed using the American notation of billion equaling $10^{9}$.

${ }^{\mathrm{f}}$ Total electricity delivered to the meter is total electricity generated divided by $(1+$ percentage T\&D losses).

${ }^{\mathrm{g}}$ Site energy in quadrillion Btu/year calculated by multiplying kWh per Rosenfeld at the meter by 3412 Btus $\mathrm{kWh}^{-1}$.

${ }^{\mathrm{h}}$ Quadrillion btus converted to exajoules using the factor 1055.1 joules/Btu.

${ }^{i}$ Primary energy in quadrillion Btu/year calculated by converting the efficiency described in footnote $\mathrm{k}$ to a heat rate (primary energy per $\mathrm{kWh}$ ), then multiplying that heat rate times $(1+$ percentage T\&D losses) and multiplying again by the number of $\mathrm{kWh}$ per Rosenfeld.

${ }^{\mathrm{j}}$ The carbon burden of coal is expressed in grams of carbon (C) per kWh of fuel (fuel converted to $\mathrm{kWh}$ assuming $3412 \mathrm{Btus} \mathrm{kWh}^{-1}$ ). This carbon burden is taken from EIA for 2006, as described in table 3 .

${ }^{\mathrm{k}}$ Power plant efficiency, in higher heating value (HHV) terms, is the average for existing US coal plants from 1996 to 2007 from table 1.

${ }^{1}$ Carbon (C) burden at the busbar (calculated in grams of carbon per kWh generated) is calculated as the ratio of the coal $\mathrm{C}$ burden from table 3 and the power plant efficiency (both in HHV terms).

${ }^{\mathrm{m}} \mathrm{C}$ burden at the meter is the carbon burden at the busbar times $(1+$ percentage $\mathrm{T} \& \mathrm{D}$ losses).

${ }^{\mathrm{n}} \mathrm{C}$ emissions in million metric tons are the product of electricity consumed at the meter and the $\mathrm{C}$ burden at the meter.

${ }^{\circ}$ Carbon dioxide emissions in million metric tonnes are equal to $\mathrm{C}$ emissions times the ratio of molecular weights of carbon dioxide (44) and carbon (12).

per year, so a full wedge is equivalent to $91700 / 3$ or about 30000 Rosenfelds (equivalent to fully eliminating 600 coalfired power plants (or $300 \mathrm{GW}$ ) for their entire 50-year lifetimes).

For those situations where the avoided carbon emissions would be quite different from those of a coal plant, we show table 5, which gives the relationship between the carbon emissions factors for a coal plant and average emissions factors for different power plant technologies (from US DOE (2009a)), for the power sectors of different countries (from
US DOE (2009b) for the US and Wheeler and Ummel (2008) for other countries), and for California (from Mahone et al (2009)). Natural gas plants are significantly less carbon intensive than coal. In places where the avoided power plant is an advanced natural gas combined cycle (typical for recently constructed gas plants) the emissions per $\mathrm{kWh}$ are $63 \%$ lower than that of an existing coal plant, resulting in annual emissions displaced of about 1 million metric tons of $\mathrm{CO}_{2}$ per year for one Rosenfeld of electricity savings. In addition, table 5 shows that China and India, two of the largest and most 
Table 5. Carbon emissions factors for electricity delivered to the meter.

\begin{tabular}{|c|c|c|c|c|c|c|}
\hline & Fuel & $\begin{array}{l}\text { Efficiency } \\
\text { HHV }(\%)\end{array}$ & $\begin{array}{l}\text { Emissions factor } \\
\mathrm{gC} / \mathrm{kWh} \text { fuel }\end{array}$ & $\begin{array}{l}\text { Emissions factor } \\
\mathrm{gC} / \mathrm{kWh} \text {.elect.delivered }\end{array}$ & $\begin{array}{l}\text { Index } \\
\text { Existing coal }=1.0\end{array}$ & Notes \\
\hline \multicolumn{7}{|l|}{ Existing plants } \\
\hline Steam turbine & Coal & 33.0 & 88.1 & 286 & 1.00 & $a, b$ \\
\hline Steam turbine & Residual oil & 32.8 & 72.6 & 237 & 0.83 & $\mathrm{a}, \mathrm{c}$ \\
\hline Steam turbine & Distillate oil & 32.8 & 68.1 & 222 & 0.78 & $\mathrm{a}, \mathrm{c}$ \\
\hline Steam turbine & Natural gas & 32.6 & 49.4 & 162 & 0.57 & $\mathrm{a}, \mathrm{c}$ \\
\hline Gas turbine & Distillate oil & 25.8 & 68.1 & 282 & 0.99 & $\mathrm{a}, \mathrm{c}$ \\
\hline Gas turbine & Natural gas & 29.8 & 49.4 & 177 & 0.62 & $\mathrm{a}, \mathrm{c}$ \\
\hline Combined cycle & Distillate oil & 31.0 & 68.1 & 235 & 0.82 & $\mathrm{a}, \mathrm{c}$ \\
\hline Combined cycle & Natural gas & 45.8 & 49.4 & 115 & 0.40 & $\mathrm{a}, \mathrm{c}$ \\
\hline \multicolumn{7}{|l|}{ New plants } \\
\hline Steam turbine, scrubbed & Coal & 37.1 & 88.1 & 254 & 0.89 & $\mathrm{a}, \mathrm{d}$ \\
\hline Advanced combined cycle & Natural gas & 50.5 & 49.4 & 105 & 0.37 & $\mathrm{a}, \mathrm{d}$ \\
\hline \multicolumn{7}{|c|}{ Average power sector carbon emissions factor by country 2007 (rank in 2007 power sector emissions in square brackets) } \\
\hline China [1] & & & & 279 & 0.98 & $\mathrm{e}$ \\
\hline United States [2] & & & & 174 & 0.61 & $\mathrm{f}$ \\
\hline India [3] & & & & 259 & 0.91 & e \\
\hline Russia [4] & & & & 156 & 0.54 & e \\
\hline Germany [5] & & & & 197 & 0.69 & e \\
\hline Japan [6] & & & & 117 & 0.41 & e \\
\hline United Kingdom [7] & & & & 179 & 0.63 & $\mathrm{e}$ \\
\hline Australia [8] & & & & 287 & 1.00 & e \\
\hline South Africa [9] & & & & 296 & 1.03 & e \\
\hline South Korea [10] & & & & 143 & 0.50 & e \\
\hline Indonesia [18] & & & & 213 & 0.74 & e \\
\hline France [27] & & & & 28 & 0.10 & e \\
\hline Brazil [44] & & & & 16 & 0.06 & e \\
\hline World average 2007 & & & & 175 & 0.61 & e \\
\hline \multicolumn{7}{|l|}{ California 2008} \\
\hline Average & & & & 119 & 0.42 & $\mathrm{~g}$ \\
\hline Marginal & & & & 156 & 0.55 & $\mathrm{~g}$ \\
\hline
\end{tabular}

a Emissions factors for fossil fuels taken from table 3.

${ }^{\text {b }}$ Steam turbine efficiency for average existing US coal plants from 1996 to 2007 taken from table 1.

${ }^{c}$ Steam turbine, gas turbine, and combined cycle efficiencies for existing oil and gas plants calculated from higher heating value (HHV) heat rates in the Electric Power Annual 2007 (US DOE 2009b), table A7, which represent an average for existing plants in 2007. The Electric Power Annual table does not differentiate between residual oil and distillate oil steam turbine efficiencies so we assume these are the same.

${ }^{\mathrm{d}}$ Efficiencies for 2008 new plants derived from heat rates in Assumptions to the AEO 2009 (US DOE 2009a), table 8.2.

${ }^{\mathrm{e}}$ Carbon emissions factors for the power sectors in different countries and the world in 2007 taken from the CARMA database (www. carma.org), documented in Wheeler and Ummel (2008). We apply 7\% T\&D losses to the CARMA emissions factors to bring them back to the meter, fully cognizant of the substantial differences in line losses between these countries but lacking any consistent data source. The total power sector emissions for the top 10 countries in 2007 represents about $77 \%$ of the world power sector total.

${ }^{\mathrm{f}}$ Average carbon emissions factors for the US in 2007 derived from $\mathrm{CO}_{2}$ emissions for central station and combined heat and power plants reported by the Electric Power Annual 2007 (US DOE 2009b) and the sum of utility sales, electricity exports, and internal electricity use for industrial customers from table 2 (also taken from Electric Power Annual 2007).

${ }^{\mathrm{g}}$ California average and marginal power sector emissions for 2008 derived as a simple average from the typical hourly average and marginal emissions factors in the model documented in Mahone et al (2009) and corrected for 7\% transmission and distribution losses to estimate the emissions factor at the meter.

rapidly growing economies, have average power sector carbon emissions factors that are close to that of the existing coal plant used in this study, indicating that most of their electricity generation comes from coal.

\section{Limitations}

All simplifications are imperfect, and this one is no exception. The specific characteristics of electricity systems (like power plant capacity factors, efficiencies, coal carbon content, and line losses) all vary greatly around the world. Thus, no single number will apply everywhere, and trying to create an approximation that perfectly characterizes all situations is futile and antithetical to the spirit of this entire exercise. So we accept that this simplification is useful, but limited.

The Rosenfeld is most useful when applied to studies of energy efficiency in isolation from the electricity supply side, because it lends context to such studies that otherwise would require a detailed analysis of avoided power plants. Even given the limitations of an approximation like this, the contextual depth and conceptual understanding that it can bring to energy efficiency studies make it well worth applying. 
One of the most important caveats to the use of this simplification relates to the load shape impacts of efficiency options, which are typically summarized in terms of conservation load factor or CLF (Koomey et al 1990a, 1990b). The Rosenfeld approximation is most accurately applied to electricity savings from a broad efficiency portfolio with CLFs between $50 \%$ and $100 \% .{ }^{4}$ It should not be used for efficiency options with low CLFs that save electricity mostly at times of peak load (like those for air conditioners), because the avoided power plants are more likely to be gas-fired peaking plants with characteristics quite different from those of coal plants.

It is most appropriate to apply the Rosenfeld to annual electricity savings. To fully displace a power plant, which typically lasts for fifty years, efficiency savings will need to continue for the life of that plant. Analysts should use caution when treating cumulative electricity savings over time with this approximation.

Policy studies assessing the emissions reductions from efficiency and supply side options will generally distinguish between the average and marginal emissions factors for the power system. The marginal emissions factor is the reduction in emissions from decreased power generation divided by the amount of electricity savings driving those reductions (it can be calculated for either the short or long run). The estimated long run marginal emissions savings may or may not equal the emissions savings for coal plants calculated above (and they vary greatly by utility, state, or country, as shown in table 5). Care must therefore be used when applying the Rosenfeld to the results from emissions reduction studies.

To retire a power plant, the most important condition is that there be a resource to displace the generation of that plant, be it energy efficiency or another power plant. Of course, the choice of which power plant to retire is a function of economics-more specifically, it is a function of the economic incentives facing the electric utility, and the utility's incentives may or may not be aligned with the optimal outcome for society. Many existing coal plants are fully depreciated and their marginal costs are low. In the absence of a change in policy, the utility won't retire these plants-instead, new resources will be deferred or other, higher marginal cost resources will be displaced.

The amount of carbon savings calculated in this letter for one Rosenfeld (based on an avoided existing coal plant) assumes that one or more additional things happen to affect this economic calculus.

(1) A price on carbon emissions will be put in place that significantly raises the marginal cost of coal plants;

(2) increased regulation of criteria pollutant emissions will create large retrofit costs or increased marginal costs (many existing coal plants have up until now been 'grandfathered' so that they are allowed to emit many more criteria pollutants than new coal plants); and/or;

\footnotetext{
4 Studies that estimate peak demand impacts for a broad range of efficiency options typically calculate aggregate CLFs close to the average utility load factor of about $60 \%$. For example, the comprehensive study by Rufo and Coito (2002), which estimated CLFs for electricity efficiency options throughout the California economy, found the aggregate CLFs in the various scenarios to range between $57 \%$ and $66 \%$.
}

(3) retiring coal plants will become an explicit policy goal and incentives or standards will be put in place to encourage this outcome.

Because of the urgency of the climate problem and because of coal's significant contribution to it, we believe these changes are likely for many countries in the coming decade. Each of these actions represents a significant shift from the status quo, but more importantly, they represent an internalization of societal costs that heretofore have not been included in the operational and investment decisions of electric utilities. They are not by themselves sufficient to guarantee significant coal plant retirements, but in combination with investments in energy efficiency or new low carbon power generation resources (which would be the driving force for such retirements) they would allow that outcome.

\section{Conclusions}

The Rosenfeld can best be used in rough back-of-the-envelope calculations and high-level summaries of analysis results for less technical audiences. If an efficiency technology or policy would save $3 \mathrm{BkWh} /$ year at the meter, it saves one Rosenfeld, or one $500 \mathrm{MW}$ coal plant operating at $70 \%$ capacity factor in that year (assuming 7\% T\&D losses). It also saves 3 million metric tons of $\mathrm{CO}_{2}$ /year (assuming all the savings come from conventional coal plants). In addition, avoiding 600 coalfired power plants of this size over their 50-year lifetimes (i.e. $50 \times 600$ or 30000 Rosenfelds) saves the same amount of carbon dioxide (about $90000 \mathrm{MtCO}_{2}$ ) as one Pacala/Socolow wedge, which is a nice link to another widely used analytical simplification of this type.

These parameters satisfy the initial criteria of simplicity of presentation, ease of recall, intuitive plausibility, physical meaning, and policy relevance. We encourage other analysts to use this new unit as a way to increase conceptual understanding of the scope of the climate challenge and to honor Art Rosenfeld, whose efforts to create a more hopeful and sustainable future continue to inspire us all.

\section{Acknowledgments}

The original idea for this letter came from Chris Calwell of Ecos Consulting. Jonathan Koomey, who was a PhD student of Dr Rosenfeld's from 1985 to 1990, conducted the analysis and the writing, with comments and other contributions from the coauthors (who are all friends and colleagues of Art's). Many colleagues reviewed the drafts, including Rob Socolow and two anonymous reviewers, and we owe them our thanks. Glenn McGrath and Channele Wirman at EIA deserve our special thanks for supplying data from and timely explanations about the EIA-860 and EIA-906/920/923 data files. All errors and omissions are the authors' responsibility alone.

\section{References}

APS 2008 Energy Future: Think Efficiency (College Park, MD: American Physical Society) September, available at www.aps. org/energyefficiencyreport/ 
Black R 2009 'Safe' climate means 'no to coal' BBC News (April 29) cited http://news.bbc.co.uk/2/hi/science/nature/8023072.stm

Brohard G J, Brown M L, Cavanagh R, Elberling L E, Hernandez G R, Lovins A and Rosenfeld A 1998 Advanced Customer Technology Test for Maximum Energy Efficiency (ACT2) Project: The Final Report (San Francisco, CA: PG\&E) http://207.67.203.54/qelibrary4_p40007_documents/ACT2/ act2fnl.pdf

Brown M A, Levine M D, Short W and Koomey J G 2001 Scenarios for a clean energy future Energy Policy 29 1179-96 (also LBNL-48031)

Brown R, Borgeson S, Koomey J and Biermayer P 2008 US Building-Sector Energy Efficiency Potential (Berkeley, CA: Lawrence Berkeley National Laboratory) September, available at http://enduse.lbl.gov/info/1096E-abstract.html LBNL-1096E

Caldeira K, Jain A K and Hoffert M I 2003 Climate sensitivity uncertainty and the need for energy without $\mathrm{CO}_{2}$ emission Science 299 2052-4

Calwell C and Moorefield L 2008 Efficiency in a Climate-Constrained World: Are We Aiming High Enough? (Asilomar, CA: American Council for an Efficient Economy)

Carnahan W, Ford K W, Prosperetti A, Rochlin G I, Rosenfeld A H, Ross M, Rothberg J, Seidel G and Socolow R H (ed) 1975 Efficient Use of Energy: Part 1-A Physics Perspective (AIP Conf. Proc.vol 25) (New York: American Institute of Physics)

Craig P, Gadgil A and Koomey J 2002 What can history teach us?: a retrospective analysis of long-term energy forecasts for the US Annual Review of Energy and the Environment 2002 ed R H Socolow, D Anderson and J Harte (Palo Alto, CA: Annual Reviews) pp 83-118 (also LBNL-50498)

Darmstadter J, Dunkerley J and Alterman J 1977 How Industrial Societies Use Energy (Baltimore, MD: Johns Hopkins University Press)

EPRI 2009 Assessment of Achievable Potential from Energy Efficiency and Demand Response Programs in the US (2010-2030) 1016987 (Palo Alto, CA: Electric Power Research Institute) January 14, available at http://mydocs.epri.com/docs/ public/000000000001018363.pdf

International Energy Agency (IEA) 1997 Indicators of Energy Use and Efficiency: Understanding the Link between Energy and Human Activity (Paris: OECD/IEA)

Koomey J G 1984 Energy policy in transition: the rise of conservation A B Honors Thesis History of Science Department, Harvard University

Koomey J G 1990 Energy efficiency choices in new office buildings: an investigation of market failures and corrective policies $P h D$ Thesis Energy and Resources Group, University of California, Berkeley, available at http://enduse.lbl.gov/Projects/ EfficiencyGap.html

Koomey J G, Atkinson C, Meier A, McMahon J E, Boghosian S, Atkinson B, Turiel I, Levine M D, Nordman B and Chan P 1991 The Potential for Electricity Efficiency Improvements in the US Residential Sector Lawrence Berkeley Laboratory, LBL-30477, July, available at http://enduse.lbl.gov/info/30477-abstract.html

Koomey J G and Hultman N E 2007 A reactor-level analysis of busbar costs for US nuclear plants, 1970-2005 Energy Policy 35 5630-42

Koomey J G, Rosenfeld A H and Gadgil A K 1990a Conservation screening curves to compare efficiency investments to power plants Energy Policy 18 774-82

Koomey J G, Rosenfeld A H and Gadgil A K 1990b Conservation screening curves to compare efficiency investments to power plants: applications to commercial sector conservation programs Proc. 1990 ACEEE Summer Study on Energy Efficiency in Buildings (Asilomar, CA: American Council for an Energy Efficient Economy)

Koomey J G, Sanstad A H and Shown L J 1996 Energy-efficient lighting: market data, market imperfections, and policy success Contemp. Econ. Policy 14 (3) 98-111 (also LBL-37702.REV) available at http://enduse.lbl.gov/info/37702-abstract.html
Koomey J G, Webber C A, Atkinson C S and Nicholls A 2001 Addressing energy-related challenges for the US buildings sector: results from the clean energy futures study Energy Policy 29 1209-22 (also LBNL-47356)

Krause F, Bach W and Koomey J G 1992 Energy Policy in The Greenhouse (New York: Wiley)

Krause F and Eto J 1988 Least-Cost Utility Planning: A Handbook for Public Utility Commissioners (v.2): The Demand Side: Conceptual and Methodological Issues (Washington, DC: National Association of Regulatory Utility Commissioners)

Krause F, Haites E, Howarth R and Koomey J G 1993 Cutting Carbon Emissions-Burden or Benefit?: The Economics of Energy-Tax and Non-Price Policies (El Cerrito, CA: International Project for Sustainable Energy Paths)

Krause F, Olivier D and Koomey J 1995 Negawatt Power: The Cost and Potential of Low-Carbon Resource Options in Western Europe (El Cerrito, CA: International Project for Sustainable Energy Paths)

Levine M D and Craig P P 1985 A decade of united states energy policy Annual Review of Energy 1985 ed J M Hollander (Palo Alto, CA: Annual Reviews) pp 557-87

Lovins A B 1979 Soft Energy Paths: Toward a Durable Peace (New York: Harper Colophon Books)

Lovins A B 1992 Energy-Efficient Buildings: Institutional Barriers and Opportunities E-Source, Strategic Issues Paper (December)

Lovins A B 2005 Energy End-Use Efficiency (Amsterdam: Rocky Mountain Institute for InterAcademy Council) September 19, available at www.rmi.org/images/other/Energy/ E05-16_EnergyEndUseEff.pdf

Lovins A B, Kyle Datta E, Bustnes O-E, Koomey J G and Glasgow N J 2004 Winning the Oil Endgame: Innovation for Profits, Jobs, and Security (Old Snowmass, CO: Rocky Mountain Institute) September, available at www.oilendgame. com

Mahone A, Price S and Morrow W 2009 Developing a Greenhouse Gas Tool for Buildings in California: Methodology and User's Manual (San Francisco, CA: Energy and Environmental Economics) January, available at www.ethree.com/ E3_Public_Docs.html

Meier A, Wright J and Rosenfeld A H 1983 Supplying Energy Through Greater Efficiency (Berkeley, CA: University of California Press)

Meinshausen M, Meinshausen N, Hare W, Raper S C B, Frieler K, Knutti R, Frame D J and Allen M R 2009 Greenhouse-gas emission targets for limiting global warming to $2^{\circ} \mathrm{C}$ Nature 458 1158-62

Pacala S and Socolow R 2004 Stabilization wedges: solving the climate problem for the next 50 years with current technologies Science 305 968-72

Rosenfeld A, Atkinson C, Koomey J G, Meier A, Mowris R and Price L 1993 Conserved energy supply curves Contemp. Policy Issues 11 45-68 (also LBL-31700)

Rosenfeld A H 1999 The art of energy efficiency: protecting the environment with better technology Annual Review of Energy and the Environment 1999 ed J M Hollander (Palo Alto, CA: Annual Reviews) pp 33-82

Rosenfeld A H and Hafemeister D 1988 Energy-efficient buildings Sci. Am. 258 (4) 78-85

Rosenfeld A H and Kumar S 2001 Tables to Convert Energy or $\mathrm{CO}_{2}$ (Saved or Used) to Familiar Equivalents-Cars, Homes, or Power Plants (US Average Data for 1999) (Sacramento, CA: California Energy Commission) May, available at www.energy. ca.gov/commissioners/rosenfeld_docs/ Equivalence-Matrix_2001-05.pdf

Rufo M and Coito F 2002 California's Secret Energy Surplus: the Potential for Energy Efficiency (San Francisco, CA: The Energy Foundation and The Hewlett Foundation) www.ef.org/ documents/Secret_Surplus.pdf 
Schipper L and Lichtenberg A J 1976 Efficient energy use and well-being: the Swedish example Science 194 1001-13

Schipper L, Meyers S, Howarth R and Steiner R 1992 Energy Efficiency and Human Activity: Past Trends, Future Prospects (New York: Cambridge University Press)

US DOE 2008 Annual Energy Review 2007 (Washington, DC: Energy Information Administration, US Department of Energy) www.eia.doe.gov/aer/ DOE/EIA-0384(2007) June

US DOE 2009a Assumptions to the Annual Energy Outlook 2009, with Projections to 2030 (Washington, DC: Energy Information
Administration, US Department of Energy) www.eia.doe.gov/ oiaf/aeo/assumption/ DOE/EIA-0554(2009) March

US DOE 2009b Electric Power Annual 2007 (Washington, DC:

Energy Information Administration, US Department of Energy) http://www.eia.doe.gov/cneaf/electricity/epa/epa_sum.html DOE/EIA-0348(2007) January 21

Wheeler D and Ummel K 2008 Calculating CARMA: Global Estimation of CO2 Emissions From the Power Sector Center for Global Development, Working Paper 145, May, available at www.cgdev.org/content/publications/detail/16101/ 